\title{
АККЛИМАТИЗАЦИЯ ВИТРОКУЛЬТУРЫ ЛАВАНДЫ УЗКОЛИСТНОЙ (Lavadula angustifolia MILL.)
}

\author{
Кузьмина Эльвира, Грати В. \\ Ботанический Сад (Институт) им. Александру Чуботару, Кишинев, Республика Молдова \\ e-mail: ello4ka-kuzmina@mail.ru
}

Род лаванда относится к семейству Lamiaceae и включает около 30 видов, растение имеет очень стойкий и сильный аромат. Растет повсеместно на территории Канарских островов в восточной Африке, на юге Европы, в Аравии и Индии. Это вечнозелёный полушаровидной формы кустарник, высотой 40-60 см. Корень деревянистый стержневой на нижних одревесневающих ветвях развиваются многочисленные побеги: цветоносные побеги четырехгранные с длинным верхним междоузлием. L.angustifolia имеет сидячие супротивные листья, продолговато-линейной формы, цвета серо-зеленого из-за опушения, длиной до 6 см. Цветет лаванда с мая по август, цветки лаванды образуют колосовидное соцветие, собранные в ложные мутовки с палитрой от бело-голубого до лилово-фиолетового цвета. Переносит морозы не ниже чем $-18^{\circ} \mathrm{C}$, не боится засухи. Спектр применения у неё очень широк: косметология, медицина и кулинария. Эфирное масло лаванды находит применение как универсальное средство в косметологии, ароматерапии. Лавандовый мед один из самых целебных сортов меда. $\mathrm{C}$ давних пор применение лаванды оправдано как противовоспалительное, противосудорожное и нормализующее деятельность нервной системы средство. Полезные свойства лаванды применяют и используют в качестве отваров, чаев из цветов лаванды, компрессов и ванн с целительным лавандовым маслом.

В лаборатории Эмбриологии и биотехнологии Ботанического сада (Институт) им. А.Чуботару разработали технологию размножения и выращивания этого вида посредством витрокультуры. Метод культуры in vitro давно уже стал массовым методом размножения ценных сортов различных культур, в том числе и лаванды. Для адаптации и акклиматизации растений, полученных in vitro, в открытом грунте им требуются совершенно новые условия, то есть необходим промежуточный этап для последовательной адаптации. Цель настоящей работы была разработка технологии выращивания и подбор субстратов для эксплантов лаванды в условиях ex vitro и определение оптимальных климатических условий их закаливания. Нами были протестированы четыре варианта субстратов, с использованием дерновой почвы, речного песка, торфа и перлита, в различных весовых соотношениях. При этом важно было определить, какой вариант субстрата больше подходит для растений, полученных in vitro, без корней и с их наличием. Экспериментально определяли приживаемость растений, выращенные в in vitro совершенно без корней и со слабой корневой системой, сформированной в in vitro. При приготовлении субстрата, многократно промытый песок, вместе с торфом стерилизуем при $\mathrm{T}^{\circ} 110^{\circ} \mathrm{C}$. Экспланты, субстрат и контейнер предварительно обработали водным раствором перманганата калия в концентрации $0,2 \%$. Посаженные экспланты, размещали в специальное помещение и держали под плёнкой. Ежедневно, на протяжении месяца 3-4 в течении дня по 5-10 минут их проветривали, спрыскивали водой и оставляли их при комнатной температуре. Через месяц хорошо развитые растения, с 2-3 боковыми побегами и хорошо развитой корневой системой, пересаживали в контейнеры, для дальнейшего развития с субстратом из дерновой почвы, торфа, речного песка и листовой подстилки $(2: 1: 1: 1)$.

Проведенные нами исследования показали, что лучшим субстратом для адаптации и укоренения растений, полученных в in vitro, служит смесь, состоящая из речного песка и перлита (1:1). Приживаемость растений-эксплантов, выращенных в условиях in vitro без сформировавшихся корней, составило 70\%, а с корневой системой, составило 90\%. 